\title{
Multiday acute sodium bicarbonate intake improves endurance capacity and reduces acidosis in men
}

Sandro Manuel Mueller ${ }^{1}$, Saskia Maria Gehrig ${ }^{1}$, Sebastian Frese ${ }^{1,2}$, Carsten Alexander Wagner ${ }^{3,4}$, Urs Boutellier ${ }^{1,3,4}$ and Marco Toigo $1,3,4^{*}$

\begin{abstract}
Background: The purpose was to investigate the effects of one dose of $\mathrm{NaHCO}_{3}$ per day for five consecutive days on cycling time-to-exhaustion ( $\left.T_{\mathrm{lim}}\right)$ at 'Critical Power' (CP) and acid-base parameters in endurance athletes.

Methods: Eight trained male cyclists and triathletes completed two exercise periods in a randomized, placebo-controlled, double-blind interventional crossover investigation. Before each period, CP was determined. Afterwards, participants completed five constant-load cycling trials at CP until volitional exhaustion on five consecutive days, either after a dose of $\mathrm{NaHCO}_{3}\left(0.3 \mathrm{~g} \cdot \mathrm{kg}^{-1}\right.$ body mass) or placebo $\left(0.045 \mathrm{~g} \cdot \mathrm{kg}^{-1}\right.$ body mass $\left.\mathrm{NaCl}\right)$.

Results: Average $T_{\lim }$ increased by $23.5 \%$ with $\mathrm{NaHCO}_{3}$ supplementation as compared to placebo $(826.5 \pm 180.1 \mathrm{vs}$. $669.0 \pm 167.2 \mathrm{~s} ; P=0.001)$. However, there was no time effect for $T_{\lim }(P=0.375)$. $\left[\mathrm{HCO}_{3}{ }^{-}\right.$] showed a main effect for condition $\left(\mathrm{NaHCO}_{3}: 32.5 \pm 2.2 \mathrm{mmol} \cdot \mathrm{I}^{-1}\right.$; placebo: $\left.26.2 \pm 1.4 \mathrm{mmol} \cdot \mathrm{I}^{-1} ; P<0.001\right)$ but not for time $(P=0.835) . \mathrm{NaHCO}_{3}$ supplementation resulted in an expansion of plasma volume relative to placebo $(P=0.003)$.

Conclusions: The increase in $T_{\lim }$ was accompanied by an increase in $\left[\mathrm{HCO}_{3}{ }^{-}\right]$, suggesting that acidosis might be a limiting factor for exercise at $\mathrm{CP}$. Prolonged $\mathrm{NaHCO}_{3}$ supplementation did not lead to a further increase in $\left[\mathrm{HCO}_{3}{ }^{-}\right]$due to the concurrent elevation in plasma volume. This may explain why $T_{\lim }$ remained unaltered despite the prolonged $\mathrm{NaHCO}_{3}$ supplementation period. Ingestion of one single $\mathrm{NaHCO}_{3}$ dose per day before the competition during multiday competitions or tournaments might be a valuable strategy for performance enhancement.
\end{abstract}

Trial registration: ClinicalTrials.gov Identifier: NCT01621074

Keywords: Critical power, Supplementation, Plasma volume, Placebo, Endurance, Sodium

\section{Background}

Competitive sports performance is strongly dependent on optimal muscle function. During cycling exercise across the heavy and severe intensity domains [1], energy is provided more and more by anaerobic glycolysis. This leads to an increased rate of accumulation of metabolites, which have been linked with muscle fatigue (e.g. $\mathrm{P}_{\mathrm{i}}$, ADP, $\mathrm{H}^{+}$, and extracellular $\mathrm{K}^{+}$). Cycling exercise at the threshold between the heavy and severe domain, i.e. at 'Critical Power' (CP), can, in contrast to the theoretical concept

\footnotetext{
* Correspondence: marco.toigo@hest.ethz.ch

'Exercise Physiology, Institute of Human Movement Sciences, ETH Zurich, Zurich, Switzerland

${ }^{3}$ Institute of Physiology, University of Zurich, Zurich, Switzerland Full list of author information is available at the end of the article
}

[2], only be sustained for as long as 20 to $40 \mathrm{~min}$ [3] before task failure. Furthermore, it was shown that $\mathrm{CP}$ overestimates the highest possible metabolic steady state $[4,5]$ and, consequently, that exercise at or above $\mathrm{CP}$ is associated with a decline in muscle and blood $\mathrm{pH}[6,7]$. An activity-induced decrease in intracellular $\mathrm{pH}$ has been suggested to limit exercise because it inhibits glycogenolysis and glycolysis [8], increases muscular $\mathrm{K}^{+}$-release [9] and inhibits sarcoplasmatic $\mathrm{Ca}^{2+}$-release $[10,11]$. Furthermore, it induces a metabolic acidosis that might impair muscle function [12] and compromise performance. To blunt the fall in intracellular $\mathrm{pH}$ and prolong time-to-exhaustion $\left(T_{\text {lim }}\right)$, nutritional modulation might be a promising avenue. With respect to endurance exercise, to date especially sodium bicarbonate $\left(\mathrm{NaHCO}_{3}\right)$ has gained

\section{Ciomed Central}

(c) 2013 Mueller et al.; licensee BioMed Central Ltd. This is an Open Access article distributed under the terms of the Creative Commons Attribution License (http://creativecommons.org/licenses/by/2.0), which permits unrestricted use, distribution, and reproduction in any medium, provided the original work is properly cited. 
much attention. However, the mechanisms by which $\mathrm{NaHCO}_{3}$ ingestion may enhance performance are not fully understood. It is believed that $\mathrm{NaHCO}_{3}$ ingestion leads to an increase in blood bicarbonate concentration $\left(\left[\mathrm{HCO}_{3}{ }^{-}\right]\right)$, which in turn increases extracellular buffer capacity. More precisely, it is proposed that the higher $\left[\mathrm{HCO}_{3}{ }^{-}\right]$gradient between blood and the intramyocellular compartment enhances $\mathrm{H}^{+}$-efflux out of the muscle cell, thereby delaying the fall in intracellular $\mathrm{pH}$ [13], which in turn may delay an impairment in optimal muscle function and performance $[14,15]$. Therefore, $\mathrm{NaHCO}_{3}$ supplementation would be expected to improve $T_{\mathrm{lim}}$ at CP if muscle $\mathrm{pH}$ is a limiting factor for exercise tolerance.

Basically, three types of $\mathrm{NaHCO}_{3}$ supplementation protocols can be applied: acute (single dose), chronic (multiple dose) and multiday acute supplementation (one dose per day before competition for consecutive days of competition). During the acute delivery mode participants take one single dose (mostly $0.3 \mathrm{~g} \cdot \mathrm{kg}^{-1}$ body mass $\left.\mathrm{NaHCO}_{3}\right) 60$ to 90 min before the start of competition. During the chronic delivery mode participants take a daily amount of $\mathrm{NaHCO}_{3}$ (mostly $0.5 \mathrm{~g} \cdot \mathrm{kg}^{-1}$ body mass), divided in 2 to 3 portions, for several days before competition takes place. On the day of competition, no $\mathrm{NaHCO}_{3}$ is consumed [16,17]. The multiday acute delivery mode comprises the ingestion of acute doses on consecutive days of competition. In contrast to the chronic loading protocol, acid-base balance is perturbed on every day during the multiday acute delivery mode. This fact leads to major differences regarding the acid-base status and accordingly the underlying mechanisms as well as the effectiveness of the different delivery modes. While the acute and chronic supplementation protocols are scientifically well described, data on the effects of multiday acute supplementation are lacking. There are several studies, which investigated $\mathrm{NaHCO}_{3}$ ingestion during tournament-like sports, but only for single events. For example, it was shown that $\mathrm{NaHCO}_{3}$ supplementation increases tennis performance [18] but does not affect prolonged intermittent cycling exercise performance [19]. However, up to date, no study investigated the effect of a consecutive multiday supplementation on consecutive multiday performance. Since consecutive, acute-load daily use of $\mathrm{NaHCO}_{3}$ might represent an interesting option to increase performance during multiday competitions or tournaments that involve exercise in the heavy and severe intensity domains, further research is warranted. In particular, scientific knowledge is limited with respect to the recovery of the body's acid-base balance after high-intensity exercise with $\mathrm{NaHCO}_{3}$ supplementation and consequently, the initial positions on the following days remain elusive.

Thus, the purpose of this randomized, placebo-controlled, double-blind interventional crossover study was to investigate if multiday acute $\mathrm{NaHCO}_{3}$ supplementation in well-trained endurance athletes leads to changes in $T_{\lim }$ at CP during constant-load cycle ergometer trials on a day-to-day basis with daily acute $\mathrm{NaHCO}_{3}$ vs. placebo supplementation for 5 days. Furthermore, we aimed to investigate if differences in $T_{\lim }$ can be explained by alterations in $\left[\mathrm{HCO}_{3}{ }^{-}\right]$and if the high amount of ingested $\mathrm{Na}^{+}$influences plasma volume (PV) and thus $\left[\mathrm{HCO}_{3}{ }^{-}\right]$. Given that exercise at or above $\mathrm{CP}$ leads to muscle and blood acidification [6,7], and that $\left[\mathrm{HCO}_{3}{ }^{-}\right]$increases extracellular buffer capacity [13], we hypothesized that consecutive, acute-load daily supplementation of $\mathrm{NaHCO}_{3}$ increases $T_{\text {lim }}$ relative to placebo. We assumed that an increase in $\left[\mathrm{HCO}_{3}{ }^{-}\right]$after the first intake is responsible for the rise in $T_{\text {lim. }}$. Since during multiday $\mathrm{NaHCO}_{3}$ intake, a high amount of $\mathrm{Na}^{+}$is ingested and absorbed, detrimental effects on endurance performance are possible. In fact, a higher $\left[\mathrm{Na}^{+}\right]$leads to water retention and thereby results in PV expansion [20]. An increase in PV decreases blood ion concentrations, and as such results in a diminished $\left[\mathrm{HCO}_{3}{ }^{-}\right]$, which in turn could counteract the benefits associated with $\mathrm{NaHCO}_{3}$ intake. It is therefore questionable, whether $\left[\mathrm{HCO}_{3}{ }^{-}\right]$can be increased beyond the concentration reached after the first day of supplementation on all subsequent days of supplementation. Consequently, we hypothesized that PV expands following a high $\mathrm{Na}^{+}$ intake, limiting any further increase in $\left[\mathrm{HCO}_{3}{ }^{-}\right]$, and consequently $T_{\text {lim }}$, beyond that observed after the first day of supplementation.

\section{Methods}

\section{Participants}

Eleven well-trained male cyclists and triathletes volunteered to participate in this study. The participants were recruited from different cycling or triathlon clubs. Two of them were excluded from the analysis because they contravened our instructions. One participant did not refrain from high-intensity exercise and the other markedly increased the training volume during or before the second testing sessions (see below). Another participant had to abort the measurements because of illness. The physical characteristics of the remaining eight participants were (mean \pm SD) age $31.4 \pm 8.8$ years, height $184.6 \pm 6.5 \mathrm{~cm}$, body mass $74.1 \pm 7.4 \mathrm{~kg}$, peak power output $\left(P_{\text {peak }}\right)$ during ramp test $402.0 \pm 29.1 \mathrm{~W}$, peak oxygen uptake $\left(\dot{V} \mathrm{O}_{2 \text { peak }}\right)$ $61.0 \pm 4.3 \mathrm{ml} \cdot \mathrm{kg}^{-1} \cdot \mathrm{min}^{-1}$. These athletes were all involved in their early preparation phase of training (pre-season). During this phase, the training consisted of constant-load rides at low-intensity. The participants were instructed to maintain their individual, low-intensity training programs. Additionally, they were advised to refrain from any high-intensity exercise during the testing sessions and to continue their nutritional habits. The determination of $\mathrm{CP}$ after the wash-out phase served to ascertain that no 
training effect occurred during the first phase of the study. None of the participants included was currently using buffer substances or any other ergogenic agents that may have compromised the administration of $\mathrm{NaHCO}_{3}$. Participants were fully informed about the purposes, benefits and risks associated with this study and completed a routine health questionnaire before giving written informed consent. This study was approved by the Swiss Federal Institute of Technology Zurich (ETH) ethics committee and was conducted in accordance with the Declaration of Helsinki.

\section{Experimental overview}

Using a randomized, placebo-controlled, double-blind interventional crossover design, all participants completed two exercise periods, each consisting of ten testing sessions (Figure 1). These periods were separated by at least one week and on average $2.3 \pm 2.1$ weeks of washout, during which the participants maintained their low-intensity training programs. During both periods, the first five tests were conducted to determine $\mathrm{CP}$ and consisted of one incremental test and four constant-load tests to volitional exhaustion. The determination of $\mathrm{CP}$ was followed by a five-day intervention period, which was conducted either with $\mathrm{NaHCO}_{3}$ or sodium chloride $(\mathrm{NaCl})$ supplementation. On each day during the intervention period, a constant-load trial at $\mathrm{CP}$ was performed. All tests were carried out under temperature-controlled laboratory conditions $\left(19-24^{\circ} \mathrm{C}\right)$ and at the same time of day. The participants had a $23 \mathrm{~h} 34 \mathrm{~min} \pm 53 \mathrm{~min}$ and $23 \mathrm{~h} 22 \mathrm{~min} \pm 45 \mathrm{~min}$ rest period between the single tests during the placebo and $\mathrm{NaHCO}_{3}$ trials, respectively. All test devices were calibrated before, and whenever indicated after each test under the terms of the manufacturer's recommendations. An independent researcher randomly assigned the two conditions to the participants and administered the non-distinguishable placebo or $\mathrm{NaHCO}_{3}$ tablets without revealing the ingredient. The investigator performing the tests was also blinded to the treatment. No feedback on test performance was given to the participants until all trials had been finished.

\section{Supplementation}

$\mathrm{NaHCO}_{3}$ was administered orally as tablets (Bullrich Salz Magentabletten, delta pronatura Dr. Krauss \& Dr. Beckmann, Egelsbach, Germany). The $\mathrm{NaHCO}_{3}$ and placebo tablets $(\mathrm{NaCl}$, delta pronatura Dr. Krauss \& Dr. Beckmann, Egelsbach, Germany) were matched by shape and taste. During the two conditions either $0.3 \mathrm{~g} \cdot \mathrm{kg}^{-1}$ body mass of $\mathrm{NaHCO}_{3}$ or $0.045 \mathrm{~g} \cdot \mathrm{kg}^{-1}$ body mass of $\mathrm{NaCl}[21,22]$ had to be ingested $90 \mathrm{~min}$ before [17] each of the five consecutive constant-load trials. Each supplement was consumed during a 15 -min period with $0.75 \mathrm{dm}^{3}$ still water to minimize gastrointestinal discomfort or any other adverse effects [8,23]. One $\mathrm{NaHCO}_{3}$ tablet contained $850 \mathrm{mg}$ of $\mathrm{NaHCO}_{3}$, whereas one placebo tablet contained $130 \mathrm{mg}$ of $\mathrm{NaCl}$, which assured the intake of equal number of pills during the varying conditions (i.e. 0.35 tablets. $\mathrm{kg}^{-1}$ body mass). If a participant's body mass was such that they required to consume a non-round number of tablets, the participants were instructed to consume the number of pills rounded to the nearest whole pill required to obtain the dose. To minimize falsification of the pill count, participants were given an unknown (to them) number of pills in excess of needs and were asked to return any remaining pills at the end of the study.

\section{Determination of 'critical power'}

Five cycle ergometer tests were performed to determine CP [24]. On the first visit, the seat and handle bar of the cycle ergometer (Ergoselect 200 K, Ergoline, Bitz, Germany) were adjusted. These settings were adopted for all consecutive trials. Participants started with a ramp cycle ergometer test to determine $P_{\text {peak }}$ and $\dot{V} \mathrm{O}_{2 \text { peak }}$. After a 3-min rest, the ramp test started at $100 \mathrm{~W}$ and involved power increases of $9 \mathrm{~W}$ every $18 \mathrm{~s}\left(30 \mathrm{~W} \cdot \mathrm{min}^{-1}\right)$ until volitional exhaustion. For all tests, participants were asked to maintain a cadence of 80 revolutions per min throughout the test. Volitional exhaustion, i.e. task failure, for all cycling tests was defined as the point in time when participants stopped pedaling or the cadence fell below 75 revolutions per minute for $>5 \mathrm{~s}$. On each of the following testing days, one constant-load trial at different power

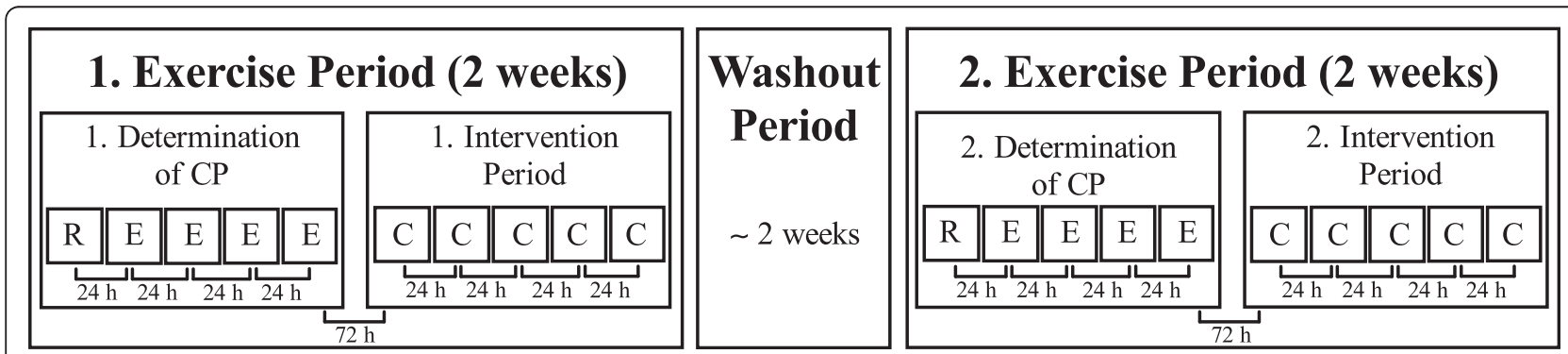

Figure 1 Study design. $C$, constant-load trials at 'Critical Power' (CP); E, constant load tests; R, incremental ramp test. 
output was completed to determine CP. After a 3-min rest, participants started with a 5 -min warm-up at $75 \mathrm{~W}$ [25]. The power was then increased immediately to $85 \%$, $90 \%$, $95 \%$ or $105 \%$ of $P_{\text {peak }}$ in a randomized order (modified from Brickley et al. [25] including the 85\% stage). These endurance capacity tests were conducted until task failure. Using the $T_{\text {lim }}$ from these tests, CP was then calculated from the linear power-time ${ }^{-1}$ equation [24].

\section{Constant-load cycling trials at 'critical power'}

During each of the two intervention periods, five constant-load trials at $\mathrm{CP}$ were completed on five consecutive days. These trials started with a 3-min rest and were followed by a 5 -min warm-up at $75 \mathrm{~W}$. Subsequently, power was immediately increased to the previously calculated CP and participants were encouraged to maintain the given cadence for as long as possible.

\section{Gas exchange and heart rate analysis}

Participants were equipped with a facemask, which covered their mouth and nose (Hans Rudolph, Shawnee, KS, USA). The facemask was connected with an antibacterial filter (PALL PRO1087, Pall, East Hills, NY, USA) to an Innocor ${ }^{\mathrm{TM}}$ device (Innocor ${ }^{\mathrm{TM}}$, Innovision, Odense, Denmark). Pulmonary gas exchange and ventilation were continuously measured breath by breath throughout all ergometer trials. Throughout all cycling tests, heart rate was recorded (Polar S610i, Polar Electro, Kempele, Finland). $\dot{V} \mathrm{O}_{2 \text { peak }}, \dot{V} \mathrm{O}_{2}$ during the constantload trials at CP $\left(\dot{V} \mathrm{O}_{2, \mathrm{CLT}}\right)$, carbon dioxide output during the constant-load trials at $\mathrm{CP}\left(\dot{V} \mathrm{CO}_{2, \mathrm{CLT}}\right)$, respiratory exchange ratio during the constant-load trials at $\mathrm{CP}$ $\left(\mathrm{RER}_{\mathrm{CLT}}\right)$ and heart rate during the constant-load trials at $\mathrm{CP}\left(\mathrm{HR}_{\mathrm{CLT}}\right)$ were determined as the highest mean over a 10 -s period. The $\dot{V} \mathrm{O}_{2}$ slow component was calculated as the difference between the changes in $\dot{V} \mathrm{O}_{2}$ between min 2 and task failure and between min 2 and 6 .

\section{Blood analysis}

For the analysis of $\left[\mathrm{HCO}_{3}^{-}\right],\left[\mathrm{Na}^{+}\right], \mathrm{pH}$ and actual base excess (ABE) $125 \mu \mathrm{l}$ blood from the same earlobe were always obtained $75 \mathrm{~min}$ after the $\mathrm{NaHCO}_{3}$ ingestions and $15 \mathrm{~min}$ before the constant-load trials at CP on 1 and day 5. Blood was collected in a heparinized glass capillary tube and analyzed using a clinical blood gas analyzer (ABL 505, Radiometer, Copenhagen, Denmark). Venous blood samples $(4 \mathrm{ml})$ were collected from the cubital vein before the constant-load trials at CP on days 1 and 5 (medica, Medizinische Laboratorien Dr. F. Kaeppeli, Zurich, Switzerland). These blood samples were analyzed for hemoglobin concentration and hematocrit, which were used to calculate changes in PV according to Dill and Costill [26].

\section{Body composition measurement}

A densitometer (Lunar iDXA ${ }^{\mathrm{TM}}$, GE Healthcare, Madison, WI, USA) was used for the determination of total lean body mass and lean soft tissue mass of the legs. Dual-energy X-ray absorptiometry (DXA) measurements were performed just before the constant-load trials every second day throughout the intervention periods to assess leg lean mass as an indicator of glycogen content. According to the DXA two-component soft tissue model, lean soft tissue mainly consists of water, proteins, glycogen and soft tissue minerals [27]. Water and glycogen content are further interconnected since each gram of glycogen binds 3-4 g of water [28]. To ensure a similar provision of carbohydrates in the immediate post-exercise period, participants were given $0.75 \mathrm{dm}^{3}$ of a regeneration drink (57 g carbohydrates. portion ${ }^{-1}$, Carbo Basic Plus, Winforce, Menzingen, Switzerland) instantly after completion of each constant-load trial.

\section{Statistical analysis}

To assess differences in $T_{\text {lim }}$, blood values, gas exchange, heart rate, and body composition a two-way repeatedmeasures ANOVA having two levels of condition $\left(\mathrm{NaHCO}_{3}\right.$ and placebo) and five levels of time (5 days of testing) was used. The assumption of sphericity was tested using Mauchly's test. If the assumption of sphericity was violated, the degrees of freedom were corrected using the Greenhouse-Geisser estimates of sphericity. When $F$ ratios were significant, post hoc comparisons of main effects were performed using a Student's paired $t$-test with Bonferroni correction. PV data were not normally distributed and thus log-transformed before using the described analysis. All data are presented as means \pm SD. The effect size is denoted as $\eta_{\mathrm{p}}^{2}$ (partial eta-squared). The level of significance was set at $P<0.05$. The statistical analyses were conducted using the software SPSS Statistics 20.0 (SPSS, Chicago, IL, USA).

\section{Results}

As judged by the leftover pill count, average compliance with $\mathrm{NaHCO}_{3}$ and placebo supplementation was $100 \%$. $T_{\text {lim }}$ increased by $23.5 \%$ following $\mathrm{NaHCO}_{3}$ ingestion $\left(F_{(1,7)}=35.45, P=0.001, \eta_{\mathrm{p}}^{2}=0.84\right.$; Figure 2a). However, there was neither an effect of time $\left(F_{(4,28)}=1.1, P=0.375\right.$, $\left.\eta_{\mathrm{p}}^{2}=0.14\right)$ nor an intervention $\mathrm{x}$ time interaction $\left(F_{(4,28)}=\right.$ $0.74, P=0.464, \eta_{\mathrm{p}}^{2}=0.01$; Figure $2 \mathrm{~b}$ ). No differences in $\mathrm{CP}$, as measured before the first and second supplementation period, could be found $(306.8 \pm 21.4 \mathrm{~W} v s$. $\left.309.0 \pm 30.4 \mathrm{~W} ; F_{(1,7)}=0.15, P=0.708, \eta_{\mathrm{p}}^{2}=0.02\right)$. Also, no difference could be found between $\mathrm{CP}$ as determined before the $\mathrm{NaHCO}_{3}$ and placebo intervention $\left(304.3 \pm 25.6 \mathrm{~W}\right.$ vs. $311.5 \pm 26.5 \mathrm{~W} ; F_{(1,7)}=1.99, P=0.202$, $\left.\eta_{\mathrm{p}}^{2}=0.22\right)$. 

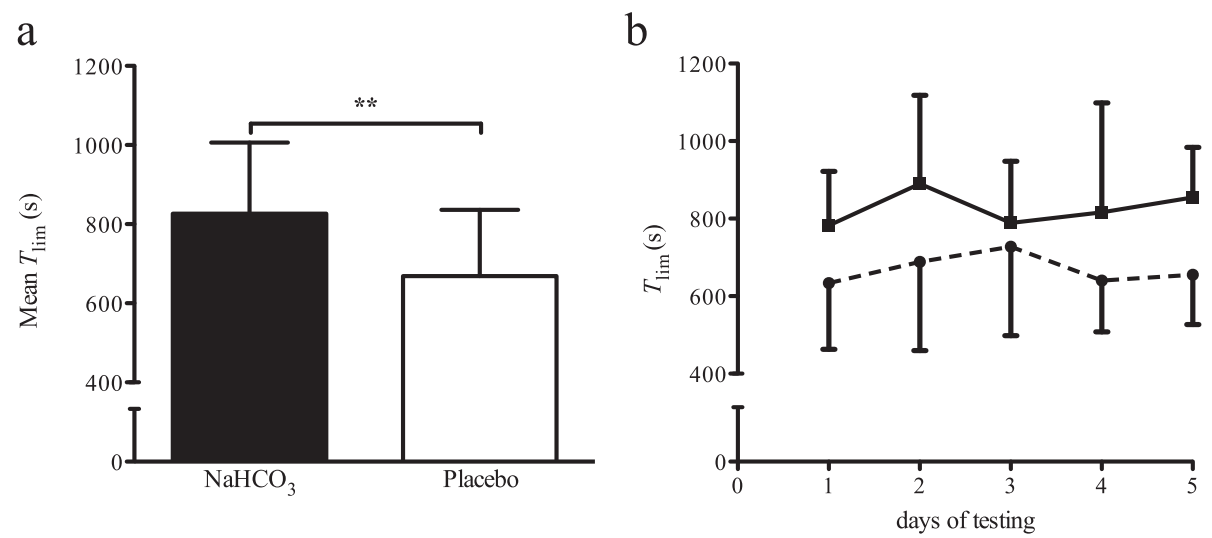

Figure 2 Time-to-exhaustion with $\mathrm{NaHCO}_{3}$ and placebo supplementation. a) Mean $\pm \mathrm{SD}$ time-to-exhaustion $\left(\mathrm{T}_{\text {lim }}\right)$ with $\mathrm{NaHCO}_{3}$ and placebo, respectively, ${ }^{*} P<0.01 ;$ b) $T_{\text {lim }}$ with $\mathrm{NaHCO}_{3}$ (solid line) and placebo (dashed line) on the 5 days of testing are presented as group mean $\pm \mathrm{SD}(n=8)$

The $\mathrm{NaHCO}_{3}$ intervention resulted in a significantly higher $\left[\mathrm{HCO}_{3}{ }^{-}\right]$relative to placebo $\left(F_{(1,7)}=118.71\right.$, $P<0.001, \eta_{\mathrm{p}}^{2}=0.94$; Table 1). However, there was neither a main effect for time $\left(F_{(1,7)}=0.05, P=0.835\right.$, $\left.\eta_{\mathrm{p}}^{2}=0.01\right)$ nor an intervention $\mathrm{x}$ time interaction $\left(F_{(1,7)}=\right.$ $\left.0.04, P=0.855, \eta_{\mathrm{p}}^{2}=0.01\right) \cdot\left[\mathrm{Na}^{+}\right]$increased after $\mathrm{NaHCO}_{3}$ $\left(F_{(1,7)}=12.44, P=0.012, \eta_{\mathrm{p}}^{2}=0.68\right)$ but remained constant with placebo supplementation. $\left[\mathrm{Na}^{+}\right]$did not significantly change over time $\left(F_{(1,7)}=0.49, P=0.509, \eta_{\mathrm{p}}^{2}=0.08\right)$ with either condition. The mean $\mathrm{ABE}$ were significantly higher during the $\mathrm{NaHCO}_{3}$ compared to the placebo trials $\left(F_{(1,7)}=100.42, P<0.001, \eta_{\mathrm{p}}^{2}=0.94\right)$, but not between days of testing $\left(F_{(1,7)}=0.01, P=0.920, \eta_{\mathrm{p}}^{2}=0.00\right)$. Blood $\mathrm{pH}$ was increased with $\mathrm{NaHCO}_{3}$ supplementation $\left(F_{(1,7)}=42.04, P<0.001, \eta_{\mathrm{p}}^{2}=0.86\right)$, showing no change between the testing days $\left(F_{(1,7)}=1.11, P=0.327\right.$, $\left.\eta_{\mathrm{p}}^{2}=0.14\right)$. There was a main effect for a PV increase during interventions $\left(F_{(1,7)}=19.22, P=0.003, \eta_{\mathrm{p}}^{2}=0.73\right.$; Table 1$)$ and days of testing $\left(F_{(1,7)}=18.12, P=0.004\right.$, $\left.\eta_{\mathrm{p}}^{2}=0.72\right)$, as well as a significant intervention $\mathrm{x}$ time interaction $\left(F_{(1,7)}=22.05, P=0.002, \eta_{\mathrm{p}}^{2}=0.76\right)$.

The $\mathrm{NaHCO}_{3}$ ingestion resulted in a significant intervention $\mathrm{x}$ time interaction for total lean body mass
$\left(F_{(1,7)}=7.77, P=0.027, \eta_{\mathrm{p}}^{2}=0.53\right.$; Table 2). In addition, total lean body mass raised over the five consecutive testing days in both conditions $\left(F_{(2,14)}=10.97, P=0.001\right.$, $\eta_{\mathrm{p}}^{2}=0.61$; Table 2). Lean soft tissue mass of the legs did not change neither during the interventions $\left(F_{(1,7)}=3.16\right.$, $\left.P=0.119, \eta_{\mathrm{p}}^{2}=0.31\right)$ nor across the days of testing $\left(F_{(2,14)}=1.38, P=0.283, \eta_{\mathrm{p}}^{2}=0.17\right.$; Table 2$)$.

$\dot{V} \mathrm{O}_{2, \text { CLT }}$ and $\dot{V} \mathrm{CO}_{2, \mathrm{CLT}}$ did not differ between the interventions $\left(F_{(1,7)}=1.453, P=0.267, \eta_{\mathrm{p}}^{2}=0.17\right.$ and $F_{(1,7)}=1.132, P=0.323, \eta_{\mathrm{p}}^{2}=0.14$; Table 3$)$ or between the days of testing $\left(F_{(2,14)}=0.631, P=0.667, \eta_{\mathrm{p}}^{2}=0.39\right.$ and $\left.F_{(2,14)}=0.145, P=0.964, \eta_{\mathrm{p}}^{2}=0.020\right)$. None of the daily $\dot{V} \mathrm{O}_{2, \text { CLT }}$ (data not shown) differed from $\dot{V} \mathrm{O}_{2 \text { peak }}\left(F_{(2,14)}=\right.$ $\left.0.081, P=0.923, \eta_{\mathrm{p}}^{2}=0.011\right)$. There was no difference in the $\dot{V} \mathrm{O}_{2}$ slow component between the $\mathrm{NaHCO}_{3}$ and placebo intervention $\left(0.08 \pm 0.31\right.$ vs. $0.03 \pm 0.28 \mathrm{l} \cdot \mathrm{min}^{-1}$ for the $\mathrm{NaHCO}_{3}$ and placebo intervention, respectively; $P=0.504)$. RER $\mathrm{CLT}_{\mathrm{CL}}$ also was not different between interventions $\left(F_{(1,7)}=2.947, P=0.130, \eta_{\mathrm{p}}^{2}=0.30\right)$ and days of testing $\left(F_{(2,14)}=0.821, P=0.523, \eta_{\mathrm{p}}^{2}=0.11\right)$. HR $\mathrm{HR}_{\mathrm{CLT}}$ decreased during the 5 testing days $\left(F_{(4,28)}=5.97, P=0.001\right.$, $\eta_{\mathrm{p}}^{2}=0.46$; Table 3) but there was no main effect for condition $\left(F_{(1,7)}=0.04, P=0.852, \eta_{\mathrm{p}}^{2}=0.01\right)$.

Table $1\left[\mathrm{HCO}_{3}{ }^{-}\right],\left[\mathrm{Na}^{+}\right], \mathrm{ABE}, \mathrm{pH}$ and $\mathrm{PV} 75$ min after supplement ingestion on the first and the fifth day of testing with either $\mathrm{NaHCO}_{3}$ or placebo supplementation

\begin{tabular}{lcccc}
\hline & \multicolumn{2}{c}{ NaHCO $_{\mathbf{3}}$} & & \multicolumn{2}{c}{ Placebo } \\
\cline { 2 - 5 } & Day 1 & Day 5 & Day 1 & Day 5 \\
\hline$\left[\mathrm{HCO}_{3}{ }^{-}\right]\left(\left.\mathrm{mmol} \cdot\right|^{-1}\right)$ & $32.4 \pm 1.8^{* * *}$ & $32.6 \pm 2.7^{* * *}$ & $26.4 \pm 1.8$ & $26.0 \pm 1.1$ \\
{$\left[\mathrm{Na}^{+}\right]\left(\left.\mathrm{mmol} \cdot\right|^{-1}\right)$} & $142.1 \pm 3.9^{*}$ & $142.4 \pm 3.0^{*}$ & $138.1 \pm 1.2$ & $139.3 \pm 5.5$ \\
$\mathrm{ABE}\left(\left.\mathrm{mmol} \cdot\right|^{-1}\right)$ & $8.4 \pm 1.7^{* * *}$ & $8.3 \pm 2.3^{* * *}$ & $2.7 \pm 1.7$ & $2.0 \pm 0.9$ \\
$\mathrm{pH}$ & $7.49 \pm 0.02^{* * *}$ & $7.48 \pm 0.02^{* * *}$ & $7.44 \pm 0.02$ & $7.43 \pm 0.02$ \\
$\mathrm{PV}(\%)$ & $55.5 \pm 2.3$ & $62.6 \pm 3.8^{\dagger+}$ & $56.0 \pm 1.7$ & $55.9 \pm 3.3$ \\
\hline
\end{tabular}

Values are mean $\pm \mathrm{SD}(n=8)$. [ $\left.\mathrm{HCO}_{3}{ }^{-}\right]$, blood bicarbonate concentration; $\left[\mathrm{Na}^{+}\right]$, blood sodium concentration; $\mathrm{ABE}$, actual base excess; $\mathrm{PV}$, plasma volume. ${ }^{*} P<0.05,{ }^{* * *} P<0.001$ relative to placebo at the same time point; ${ }^{+\dagger} P<0.01$ relative to day 1 . 
Table 2 Total lean body mass and lean soft tissue mass of the legs on the different days of testing with either $\mathrm{NaHCO}_{3}$ or placebo ingestion

\begin{tabular}{|c|c|c|c|c|c|c|}
\hline & \multicolumn{3}{|c|}{$\mathrm{NaHCO}_{3}$} & \multicolumn{3}{|c|}{ Placebo } \\
\hline & Day 1 & Day 3 & Day 5 & Day 1 & Day 3 & Day 5 \\
\hline Total lean soft tissue (kg) & $60.7 \pm 4.8$ & $61.7 \pm 5.3^{*+\dagger}$ & $62.0 \pm 5.3^{*+\dagger}$ & $60.5 \pm 5.3$ & $61.3 \pm 5.4^{\dagger \dagger}$ & $60.6 \pm 5.0$ \\
\hline Lean soft tissue legs (kg) & $21.1 \pm 2.5$ & $21.3 \pm 2.9$ & $21.4 \pm 3.0$ & $21.0 \pm 2.9$ & $21.2 \pm 2.9$ & $21.0 \pm 2.9$ \\
\hline
\end{tabular}

Values are mean $\pm \mathrm{SD}(n=8) .{ }^{*} P<0.05$ relative to placebo; ${ }^{\text {t† }} P<0.01$ relative to day 1 .

\section{Discussion}

Several new findings have been observed in this randomized, placebo-controlled, double-blind interventional crossover investigation. First, multiday $\mathrm{NaHCO}_{3}$ supplementation for 5 days increased $T_{\lim }$ at $\mathrm{CP}$ on each day relative to placebo in highly trained athletes. Second, there was no difference in the increased $T_{\lim }$ over the 5 days of supplementation with $\mathrm{NaHCO}_{3}$ or $\mathrm{NaCl}$. Third, the increase in $T_{\lim }$ was paralleled by increases in $\left[\mathrm{HCO}_{3}{ }^{-}\right], \mathrm{pH}$ and $\mathrm{ABE}$. Fourth, $\left[\mathrm{HCO}_{3}{ }^{-}\right]$and $\left[\mathrm{Na}^{+}\right]$in the blood stabilized over time in the $\mathrm{NaHCO}_{3}$ condition. Fifth, calculated PV increased during the $\mathrm{NaHCO}_{3}$ more than in the placebo intervention.

We found that $\mathrm{NaHCO}_{3}$ supplementation led to an increase in $T_{\lim }$ at $\mathrm{CP}$ and that the improvement in $T_{\lim }$ was paralleled by an increase in blood $\left[\mathrm{HCO}_{3}{ }^{-}\right], \mathrm{pH}$ and $\mathrm{ABE}$, indicating that the alteration in $T_{\lim }$ appears to be linked to an elevated extracellular buffer capacity. In fact, it has been shown that an increased $\left[\mathrm{HCO}_{3}{ }^{-}\right]$gradient between the intra- and extramyocellular compartment leads to an amplified $\mathrm{H}^{+}$-efflux from the muscle cell and delays the fall in intramyocellular $\mathrm{pH}[8,14]$. We observed a trend for higher $\left[\mathrm{La}^{-}\right]$during the constantload tests following $\mathrm{NaHCO}_{3}$ supplementation $(P=0.070$, data not shown), supporting the notion that the increased $\mathrm{H}^{+}$-concentration resulted from a lactate-proton symport. A fall in intramyocellular $\left[\mathrm{H}^{+}\right]$is associated with muscle fatigue due to 1) an inhibition of glycogenolysis and glycolysis [8], 2) increased muscular $\mathrm{K}^{+}$release, 3) lesser contractility of the heart muscle [9], 4) inhibition of the sarcoplasmatic calcium release [10] and 5) inhibition of

Table 3 Peak values during the $\mathrm{CLT}$ at $\mathrm{CP}$ for $\mathrm{VO}_{2}, \mathrm{VCO}_{2}$, RER and HR on the first and fifth day of testing with either $\mathrm{NaHCO}_{3}$ or placebo supplementation

\begin{tabular}{lccccc}
\hline & \multicolumn{2}{c}{$\mathrm{NaHCO}_{3}$} & & \multicolumn{2}{c}{ Placebo } \\
\cline { 2 - 3 } \cline { 6 - 6 } & Day 1 & Day 5 & & Day 1 & Day 5 \\
\hline $\mathrm{VO}_{2, \text { CLT }}$ & $4.64 \pm 0.39$ & $4.66 \pm 0.30$ & & $4.59 \pm 0.37$ & $4.64 \pm 0.47$ \\
$\mathrm{VCO}_{2, \text { CLT }}$ & $4.63 \pm 0.47$ & $4.67 \pm 0.19$ & & $4.58 \pm 0.36$ & $4.59 \pm 0.40$ \\
$\mathrm{RER}_{\mathrm{CLT}}$ & $1.07 \pm 0.04$ & $1.08 \pm 0.05$ & & $1.03 \pm 0.05$ & $1.05 \pm 0.05$ \\
$\mathrm{HR}$ & $177.4 \pm 8.5$ & $172.8 \pm 9.0^{* *}$ & & $176.3 \pm 7.8$ & $173.8 \pm 8.6^{* *}$
\end{tabular}

Values are mean $\pm \mathrm{SD}(n=8)$. CLT, constant-load trials; $\mathrm{CP}$, 'Critical Power'; $V_{2}$, oxygen uptake; $V \mathrm{CO}_{2}$ carbon dioxide output; RER, respiratory exchange ratio; HR, heart rate. ${ }^{* *} P<0.01$ relative to day 1 . the actin-myosin interactions [11]. Thus, delaying the fall in intramyocellular $\mathrm{pH}$ might postpone the fatigue process and prolong intact muscle function. Indeed, our results showed that the ingestion of $\mathrm{NaHCO}_{3}$ induced metabolic alkalosis, which in turn enhanced $T_{\lim }$ at $\mathrm{CP}$ and thus improved high-intensity exercise in the range of 10 to 20 min duration.

As hypothesized, $T_{\lim }$ at $\mathrm{CP}$ could be increased with $\mathrm{NaHCO}_{3}$ supplementation. This is in contrast to the theoretical model, which states that an intramyocellular metabolic steady state exists at exercise intensities up to $\mathrm{CP}$. However, our results support the notion that CP overestimates the metabolic steady state [4,5]. Furthermore, our result that $\mathrm{NaHCO}_{3}$ increased $T_{\text {lim }}$ at $\mathrm{CP}$ extends previous findings showing that $\mathrm{NaHCO}_{3}$ supplementation increases exercise above $\mathrm{CP}$ relative to placebo [14,29]. In the latter studies, short high-intensity tests, during which intramyocellular $\mathrm{pH}$ falls rapidly from the beginning of exercise, were completed. During these types of tests, the finite work capacity above $\mathrm{CP}\left(W^{\prime}\right)$ is drawn on after the start of exercise and becomes reduced. In light of our findings, these results might be interpreted to mean that $\mathrm{NaHCO}_{3}$ simply increases $W$ '. However, Vanhatalo et al. [23] showed that $\mathrm{NaHCO}_{3}$ does not increase $W^{\prime}$ during a 3-min all-out test, and concluded that changes in intramyocellular $\mathrm{pH}$ might not influence $W$ in this particular test setting, and that for short all-out exercise, [PCr] dynamics is more important in determining $W^{\prime}$. In our constant-load trials at CP, $W^{\prime}$ was supplied to a large extent by anaerobic glycolysis. Therefore, we assume that $\mathrm{NaHCO}_{3}$ supplementation increases $W$ in conditions where acidification occurs during exercise. Our result that the estimated $\dot{V} \mathrm{O}_{2}$ slow component was not different between the two interventions lends further credence to this notion, although the influence of $\mathrm{NaHCO}_{3}$ on the $\dot{V} \mathrm{O}_{2}$ slow component remains ambiguous (reduction: [30]; no change: [31]). In our study, the identical $\dot{V} \mathrm{O}_{2}$ slow component for both, the $\mathrm{NaHCO}_{3}$ and placebo condition, indicated that $\dot{V} \mathrm{O}_{2 \text { peak }}$ was attained at the same point in time. Based on the fact that the depletion of $W^{\prime}$ coincides with the attainment of $\dot{V} \mathrm{O}_{\text {2peak }}$ [32], our results indicate that $\mathrm{NaHCO}_{3}$ ingestion did not increase the rate of $W^{\prime}$ utilization but rather $W^{\prime}$ itself. Further support for our assumption comes from another study, where average power in a 60 min cycling time trial was found to be 
higher with $\mathrm{NaHCO}_{3}$ as compared to placebo [33]. During a 60 min time trial, power output will fluctuate around CP with power peaks occurring e.g. at the start and during (final) sprints. In these occasions, i.e. when exercising above CP, $W$ ' will be reduced. Consequently, a higher $W^{\prime}$ can increase performance during tests of longer duration, especially if pacing strategies are implemented.

We also found that five bolus intakes on five consecutive days did not result in an increase of $T_{\lim }$ beyond the value observed after the first intake. Thus, multiday administration of $\mathrm{NaHCO}_{3}$ did not lead to a cumulative effect on endurance capacity. Accordingly, $\left[\mathrm{HCO}_{3}{ }^{-}\right]$, blood $\mathrm{pH}$, and $\mathrm{ABE}$ after multiday $\mathrm{NaHCO}_{3}$ administration also remained unchanged relative to the initial rise after the first bolus. The most obvious explanation would be that during each CP-trial a certain amount of $\mathrm{NaHCO}_{3}$ was used, leading to lower values for $\left[\mathrm{HCO}_{3}{ }^{-}\right], \mathrm{pH}$ and $\mathrm{ABE}$ post $v$ s. pre test. During the following $24 \mathrm{~h}$ of recovery, the body would then be expected to re-establish the resting values. On the following day, the participants then would start the $\mathrm{CP}$ trial at similar (complete recovery) or lower $\left[\mathrm{HCO}_{3}{ }^{-}\right]$, blood $\mathrm{pH}$, and $\mathrm{ABE}$ (incomplete recovery) relative to the first day, whereby an additional increase in performance would not be expected. Although we did not measure $\left[\mathrm{HCO}_{3}{ }^{-}\right], \mathrm{pH}$ and $\mathrm{ABE}$ before supplementation on the following days, these two described cases can be most likely excluded. The reason for this is that $\left[\mathrm{Na}^{+}\right]$also did not increase during the consecutive 5 days of $\mathrm{NaHCO}_{3}$ supplementation despite the fact that $\mathrm{Na}^{+}$, unlike $\mathrm{HCO}_{3}{ }^{-}$, was not used as a buffer during the $\mathrm{CP}$ trials, and that the high amount of ingested $\mathrm{Na}^{+}$could not be used completely through sweating. The predicted sweating rate during exercise of $1 \mathrm{dm}^{3} \cdot \mathrm{h}^{-1}$ water, with a sweat $\left[\mathrm{Na}^{+}\right]$of $50 \mathrm{mEq} \cdot \mathrm{dm}^{3}$ [34] would have led to a $\mathrm{Na}^{+}$ loss of $\sim 0.36 \mathrm{~g}$. This calculated sweat-induced loss of $\mathrm{Na}^{+}$ corresponds to $\sim 20 \%$ of the daily $\mathrm{Na}^{+}$intake during the placebo intervention. Regarding the substantially higher $\mathrm{Na}^{+}$intake during the $\mathrm{NaHCO}_{3}$ intervention, the sweat-induced loss of $\mathrm{Na}^{+}$was negligible during this intervention.

As shown in this study, the $\mathrm{NaHCO}_{3}$ intervention led to an increase in $\left[\mathrm{Na}^{+}\right]$and plasma osmolality after the first bolus administration. This increase was counteracted by an expansion in PV. The increase in PV was to such an extent that pre-exercise blood $\left[\mathrm{HCO}_{3}{ }^{-}\right], \mathrm{pH}$, and $\mathrm{ABE}$ remained constant during the 5 days of testing. This proposed mechanism of PV expansion has already been described by Máttar et al. [35], who showed that plasma $\left[\mathrm{Na}^{+}\right]$and plasma osmolality were increased after $\mathrm{NaHCO}_{3}$ injections in acute cardiac resuscitation. Other mechanisms to counteract increases in $\left[\mathrm{Na}^{+}\right]$and plasma osmolality comprise a shift of fluid from the intra- to the extramyocellular compartment [36], a stimulation of arginine vasopressin secretion [37], which leads to an intensified water retention from the kidneys [38], and a stimulation of the thirst center whereby more fluid is consumed [37]. In accordance with our results, McNaughton et al. [29] found an increase in plasma $\left[\mathrm{Na}^{+}\right]$after the first of five doses of $\mathrm{NaHCO}_{3}$ but no further increase of plasma $\left[\mathrm{Na}^{+}\right]$on the following days. The elevation of PV in the present study is mirrored by the measured increase in DXA whole-body lean mass. In the DXA two-component soft tissue model, lean mass comprises water, proteins, glycogen and non-bone minerals [27]. As increases in protein, glycogen and non-bone minerals can virtually be excluded (see below), the increase in whole-body lean mass must have resulted from an increase in whole body water, which led to an expansion in PV. Our findings are in accordance with the report of Lands et al. [39] who found a significantly higher value for DXA-derived whole-body lean mass after saline infusion given to healthy male participants. Finally, our finding that $\mathrm{HR}_{\mathrm{CLT}}$ was reduced lends further credence to our result that PV increased as a consequence of $\mathrm{NaHCO}_{3}$ supplementation, because PV expansion simultaneously increases stroke volume and reduces sympathetic nervous activity, leaving $\dot{V} \mathrm{O}_{2, \mathrm{CLT}}$ unaffected [40].

In our study, DXA-derived leg lean mass did neither change between interventions nor over time (Table 2). As with each gram of glycogen stored in muscle tissue 3-4 $\mathrm{g}$ of water is bound [28], and body water is present within the lean soft tissue compartment [27], a decrease in leg lean mass in such a short time (2 days) would indicate a loss of glycogen. In turn, glycogen loss would implicate incomplete regeneration, which would manifest itself in a reduced anaerobic work capacity and, accordingly, decreased performance [41]. Since our participants displayed neither a reduction in leg lean mass nor performance, the provided regeneration drink and the participants' daily nutritional intake were sufficient to restore glycogen from day to day, allowing them to perform maximally on each day.

Our results have at least two practical implications. First, since the $\left[\mathrm{HCO}_{3}{ }^{-}\right]$gradient between intramyocellular compartment and blood did not decrease over time, $\mathrm{NaHCO}_{3}$ can be taken daily in multiday competitions or tournaments lasting $\leq 5 \mathrm{~d}$ without the risk of reducing performance. Second, the apparent PV expansion in response to the high ion intake (see above) blunted any further increase in $\left[\mathrm{HCO}_{3}{ }^{-}\right]$. If the same mechanism would be true for the chronic supplementation protocol, the effectiveness of this protocol should be questioned, as it seems that $\left[\mathrm{HCO}_{3}{ }^{-}\right]$cannot be increased limitlessly, i.e. that it probably reaches a ceiling. The observed ceiling effect was probably based on a metabolic compensation mechanism preventing a disproportionate increase in $\left[\mathrm{HCO}_{3}{ }^{-}\right]$. A respiratory compensation mechanism is unlikely to have occurred in our study because there were 
no differences between the $\mathrm{NaHCO}_{3}$ and placebo intervention for $\dot{V} \mathrm{CO}_{2}(P=0.903$, data not shown $)$ and RER ( $P=0.556$, data not shown) during the resting measurements before the constant-load tests. Of further note is that the standard chronic protocol comprises a daily dose of $0.5 \mathrm{~g} \mathrm{NaHCO}_{3} \mathrm{~kg}^{-1}$ body mass [42], which might accentuate the increase in $\mathrm{PV}$ and possible side effects. Thus, one adequate dose of $\mathrm{NaHCO}_{3}$ administered before the competition should be effective in mediating all of the performance-enhancing effects without the need of a "loading phase". In this context, our results expand the findings of McNaughton and Thompson [16] as well as Siegler et al. [17], who compared different acute and chronic protocols and found that there are no differences between these ingestion protocols with respect to exercise performance.

It may be argued that the present findings could be limited by 1) differences in performance ability throughout the study period and 2) decreasing motivation. Regarding the first point we have shown that $\mathrm{CP}$ was neither different between the first and second intervention period nor before the $\mathrm{NaHCO}_{3}$ and placebo condition. An increase in CP from the first to the second intervention would have indicated a training effect, whereas a decrease in $\mathrm{CP}$ would have indicated incomplete recovery. Hence, we can assume that the participants had the same performance ability throughout the study, allowing a comparison of $T_{\mathrm{lim}}$ between the two conditions. Regarding the second point, decreasing motivation in a single participant would be evident from a decrease in $T_{\lim }$ within or between interventions. Considering the single variations in $T_{\text {lim }}$ irrespective of condition, during which no distinct increases or decreases in $T_{\lim }$ over time (i.e. from the second to the fifth test day) were identified, a decreasing motivation can be excluded for all participants. In addition, $\dot{V} \mathrm{O}_{2, \text { CLT }}, \dot{V} \mathrm{CO}_{2, \text { CLT }}$ and RER $\mathrm{RLT}_{\mathrm{CLT}}$ were not different between conditions and days of testing. This indicates that the participants' effort was constant during the whole study period.

\section{Conclusion}

In conclusion, multiple acute, consecutive day $\mathrm{NaHCO}_{3}$ supplementation led to an increase in $T_{\lim }$ at $\mathrm{CP}$ after the first bolus intake. However, while $T_{\lim }$ remained elevated in the $\mathrm{NaHCO}_{3}$ condition, it was not further altered with prolonged $\mathrm{NaHCO}_{3}$ supplementation. The increase in $T_{\lim }$ was accompanied by a higher $\left[\mathrm{HCO}_{3}{ }^{-}\right]$ gradient between the blood and the intramyocellular compartment, which stabilized over time in the $\mathrm{NaHCO}_{3}$ intervention. In contrast to the theoretical CP-model, where metabolites should reach a steady state during exercise at $\mathrm{CP}$, and consequently, buffer substances should be ineffective in enhancing $T_{\mathrm{lim}}$, we showed that in practice $T_{\text {lim }}$ can be increased with $\mathrm{NaHCO}_{3}$ supplementation.
Furthermore, the high amount of ingested $\mathrm{Na}^{+}$caused a sustained elevation in PV, which inhibited a further increase in $\left[\mathrm{HCO}_{3}{ }^{-}\right]$, and consequently limited the performance-enhancing effect. Therefore, this study indicates that $\mathrm{NaHCO}_{3}$ can be taken daily in multiday competitions or tournaments to maintain performance ability throughout the whole duration of the competition.

\begin{abstract}
Abbreviations
ABE: Actual base excess; CP: Critical power; DXA: Dual-energy x-ray absorptiometry; $\left[\mathrm{HCO}_{3}{ }^{-}\right.$]: Blood bicarbonate concentration; $\mathrm{HR}_{\mathrm{CLT}}$ : Heart rate during the constant-load trials at $\mathrm{CP} ; \mathrm{NaCl}$ : Sodium chloride;

$\mathrm{NaHCO}_{3}$ : Sodium bicarbonate; $P_{\text {peak: }}$ Peak power output; PV: Plasma volume; $\mathrm{RER}_{\mathrm{CLT}}$ : Respiratory exchange ratio during the constant-load trials at $\mathrm{CP}$; $T_{\text {lim: }}$ : Time-to-exhaustion; $\dot{V} \mathrm{O}_{2 \text { peak: }}$ Peak oxygen uptake; $\dot{V} \mathrm{O}_{2, \mathrm{CLT}}: \dot{V} \mathrm{O}_{2}$ during the constant-load trials at $\mathrm{CP} ; \dot{V} \mathrm{CO}_{2, \mathrm{CLT}}$ : Carbon dioxide output during the constant-load trials at CP; $W^{\prime}$ : The finite work capacity above CP.
\end{abstract}

\section{Competing interests}

The authors declare that they have no competing interests.

\section{Authors' contributions}

SMM, SMG, MT designed the study. SMG and SMM were involved in data collection. SMG, SMM, and MT were involved in statistical analysis and drafted the manuscript. SMM, SMG, SF, UB, CAW, and MT interpreted the data and reviewed the manuscript. All authors read and approved the final manuscript.

\section{Acknowledgments}

We thank delta pronatura Dr. Krauss \& Dr. Beckmann KG (Egelsbach, Germany) and Winforce AG (Menzingen, Switzerland) for the $\mathrm{NaHCO}_{3}$ and placebo tablets, and the regeneration drink, respectively, which were kindly provided as a gift.

\section{Author details}

${ }^{1}$ Exercise Physiology, Institute of Human Movement Sciences, ETH Zurich, Zurich, Switzerland. 'Department of Neurology, University Hospital Zurich, Zurich, Switzerland. ${ }^{3}$ Institute of Physiology, University of Zurich, Zurich, Switzerland. ${ }^{4}$ Zurich Center for Integrative Human Physiology, University of Zurich, Zurich, Switzerland.

Received: 8 February 2013 Accepted: 20 March 2013 Published: 26 March 2013

\section{References}

1. Jones AM, Vanhatalo A, Burnley M, Morton RH, Poole DC: Critical power: implications for the determination of $\mathrm{VO}_{2 \max }$ and exercise tolerance. Med Sci Sports Exerc 2010, 42:1876-1890.

2. Monod H, Scherrer J: The work capacity of a synergic muscular group. Ergonomics 1965, 8:329-338.

3. Brickley G, Doust J, Williams CA: Physiological responses during exercise at critical power. Eur J Appl Physiol 2002, 88:146-151.

4. Jenkins DG, Quigley BM: Blood lactate in trained cyclists during cycle ergometry at critical power. Eur J Appl Physiol Occup Physiol 1990, 61:278-283.

5. Pringle JS, Jones AM: Maximal lactate steady state, critical power and EMG during cycling. Eur J Appl Physiol 2002, 88:214-226.

6. Jones NL, Sutton JR, Taylor R, Toews CJ: Effect of pH on cardiorespiratory and metabolic responses to exercise. J App/ Physio/ 1977, 43:959-964.

7. Jones AM, Wilkerson DP, DiMenna F, Fulford J, Poole DC: Muscle metabolic responses to exercise above and below the "critical power" assessed using ${ }^{31}$ P-MRS. Am J Physiol Regul Integr Comp Physiol 2008, 294:R585-R593.

8. Hollidge-Horvat MG, Parolin ML, Wong D, Jones NL, Heigenhauser GJ: Effect of induced metabolic alkalosis on human skeletal muscle metabolism during exercise. Am J Physiol Endocrinol Metab 2000, 278:E316-E329.

9. Fabiato A, Fabiato F: Effects of pH on the myofilaments and the sarcoplasmic reticulum of skinned cells from cardiac and skeletal muscles. J Physiol 1978, 276:233-255. 
10. Donaldson SK, Hermansen $L$, Bolles L: Differential, direct effects of $\mathrm{H}^{+}$on $\mathrm{Ca}^{2+}$-activated force of skinned fibers from the soleus, cardiac and adductor magnus muscles of rabbits. Pflugers Arch 1978, 376:55-65.

11. Lannergren J, Westerblad $\mathrm{H}$ : Force decline due to fatigue and intracellular acidification in isolated fibres from mouse skeletal muscle. J Physio/ 1991, 1991(434):307-322.

12. Fitts RH: Cellular mechanisms of muscle fatigue. Physiol Rev 1994, 74:49-94.

13. Forbes SC, Raymer GH, Kowalchuk JM, Marsh GD: $\mathrm{NaHCO}_{3}$-induced alkalosis reduces the phosphocreatine slow component during heavyintensity forearm exercise. J Appl Physiol 2005, 99:1668-1675.

14. Bishop D, Edge J, Davis C, Goodman C: Induced metabolic alkalosis affects muscle metabolism and repeated-sprint ability. Med Sci Sports Exerc 2004, 36:807-813.

15. Mainwood GW, Worsley-Brown P: The effects of extracellular $\mathrm{pH}$ and buffer concentration on the efflux of lactate from frog sartorius muscle. J Physiol 1975, 250:1-22.

16. McNaughton $L$, Thompson D: Acute versus chronic sodium bicarbonate ingestion and anaerobic work and power output. J Sports Med Phys Fitness 2001, 41:456-462

17. Siegler JC, Midgley AW, Polman RC, Lever R: Effects of various sodium bicarbonate loading protocols on the time-dependent extracellular buffering profile. J Strength Cond Res 2010, 24:2551-2557.

18. Wu CL, Shih MC, Yang CC, Huang MH, Chang CK: Sodium bicarbonate supplementation prevents skilled tennis performance decline after a simulated match. J Int Soc Sports Nutr 2010, 7:33.

19. Price MJ, Cripps D: The effects of combined glucose-electrolyte and sodium bicarbonate ingestion on prolonged intermittent exercise performance. J Sports Sci 2012, 30:975-983.

20. Heer M, Frings-Meuthen P, Titze J, Boschmann M, Frisch S, Baecker N, Beck $\mathrm{L}$ : Increasing sodium intake from a previous low or high intake affects water, electrolyte and acid-base balance differently. Brit J Nutr 2009, 101:1286-1294.

21. McNaughton L: Bicarbonate ingestion: effects of dosage on $60 \mathrm{~s}$ cycle ergometry. J Sports Sci 1992, 10:415-423.

22. Stephens TJ, McKenna MJ, Canny BJ, Snow RJ, McConell GK: Effect of sodium bicarbonate on muscle metabolism during intense endurance cycling. Med Sci Sports Exerc 2002, 34:614-621

23. Vanhatalo A, McNaughton LR, Siegler JH, Jones AM: Effect of induced alkalosis on the power-duration relationship for "all-out" exercise. Med Sci Sports Exerc 2010, 42:563-570.

24. Hill DW: The critical power concept. A review. Sports Med 1993, 16:237-254.

25. Brickley G, Green S, Jenkins DG, McEinery M, Wishart C, Doust JD, Williams CA: Muscle metabolism during constant- and alternating-intensity exercise around critical power. Int J Sports Med 2007, 28:300-305.

26. Dill DB, Costill DL: Calculation of percentage changes in volumes of blood, plasma, and red cells in dehydration. J App/ Physio/ 1974, 37:247-248.

27. Pietrobelli A, Formica C, Wang Z, Heymsfield SB: Dual-energy X-ray absorptiometry body composition model: review of physical concepts. Am J Physiol 1996, 271(6 Pt 1):E941-E951.

28. Olsson KE, Saltin B: Variation in total body water with muscle glycogen changes in man. Acta Physio/ Scand 1970, 80:11-18.

29. McNaughton L, Backx K, Palmer G, Strange N: Effects of chronic bicarbonate ingestion on the performance of high-intensity work. Eur J Appl Physiol 1999, 80:333-336.

30. Berger NJA, McNaughton LR, Keatley S, Wilkerson DP, Jones AM: Sodium bicarbonate ingestion alters the slow but not the fast phase of $\dot{\mathrm{V}} \mathrm{O}_{2}$ kinetics. Med Sci Sports Exerc 2006, 38:1909-1917.

31. Santalla A, Pérez M, Montilla M, Vicente L, Davison R, Earnest C, Lucia A: Sodium bicarbonate ingestion does not alter the slow component of oxygen uptake kinetics in professional cyclists. J Sports Sci 2003, 21:39-47.

32. Burnley M, Jones AM: Oxygen uptake kinetics as a determinant of sports performance. Eur J Sports Sci 2007, 7:63-79.

33. McNaughton L, Dalton B, Palmer G: Sodium bicarbonate can be used as an ergogenic aid in high-intensity, competitive cycle ergometry of $1 \mathrm{~h}$ duration. Eur J Appl Physiol 1999, 80:64-69.

34. Montain SJ, Cheuvront SN, Sawka MN: Exercise associated hyponatremia: quantitative analysis to understand the aetiology. Br J Sports Med 2006, 40:98-106.

35. Máttar JA, Weil MH, Shubin H, Stein L: Cardiac arrest in the critically ill: Il. Hyperosmolal states following cardiac arrest. Am J Med 1974, 56:162-168.
36. He FJ, Markandu ND, Sagnella GA, DeWardener HE, MacGregor GA: Plasma sodium: ignored and underestimated. Hypertension 2005, 45:98-102.

37. Robertson GL, Shelton RL, Athar S: The osmoregulation of vasopressin. Kidney Int 1976, 10:25-37.

38. Roos JC, Koomans HA, Dorhout Mees EJ, Delawi IM: Renal sodium handling in normal humans subjected to low, normal and extremely high sodium supplies. Am J Physiol 1985, 249(6 Pt 2):F941-F947.

39. Lands LC, Hornby L, Hohenkerk JM, Glorieux FH: Accuracy of measurements of small changes in soft-tissue mass by use of dualenergy X-ray absorptiometry. Clin Invest Med 1996, 19:279-285.

40. Kanstrup IL, Ekblom B: Acute hypervolemia, cardiac performance, and aerobic power during exercise. J Appl Physio 1982, 52:1186-1191.

41. Miura A, Sato H, Sato H, Whipp BJ, Fukuba $Y$ : The effect of glycogen depetion on the curvature constant parameter of the power-duration curve for cycle ergometry. Ergonomics 2000, 43:133-141.

42. Douroudos II, Fatouros IG, Gourgoulis V, Jamurtas AZ, Tsitsios T, Hatzinikolaou A, Margonis K, Mavromatidis K, Taxildaris K: Dose-related effects of prolonged $\mathrm{NaHCO}_{3}$ ingestion during high-intensity exercise. Med Sci Sports Exerc 2006, 38:1746-1753.

doi:10.1186/1550-2783-10-16

Cite this article as: Mueller et al:: Multiday acute sodium bicarbonate intake improves endurance capacity and reduces acidosis in men. Journal of the International Society of Sports Nutrition 2013 10:16.

\section{Submit your next manuscript to BioMed Central and take full advantage of:}

- Convenient online submission

- Thorough peer review

- No space constraints or color figure charges

- Immediate publication on acceptance

- Inclusion in PubMed, CAS, Scopus and Google Scholar

- Research which is freely available for redistribution 